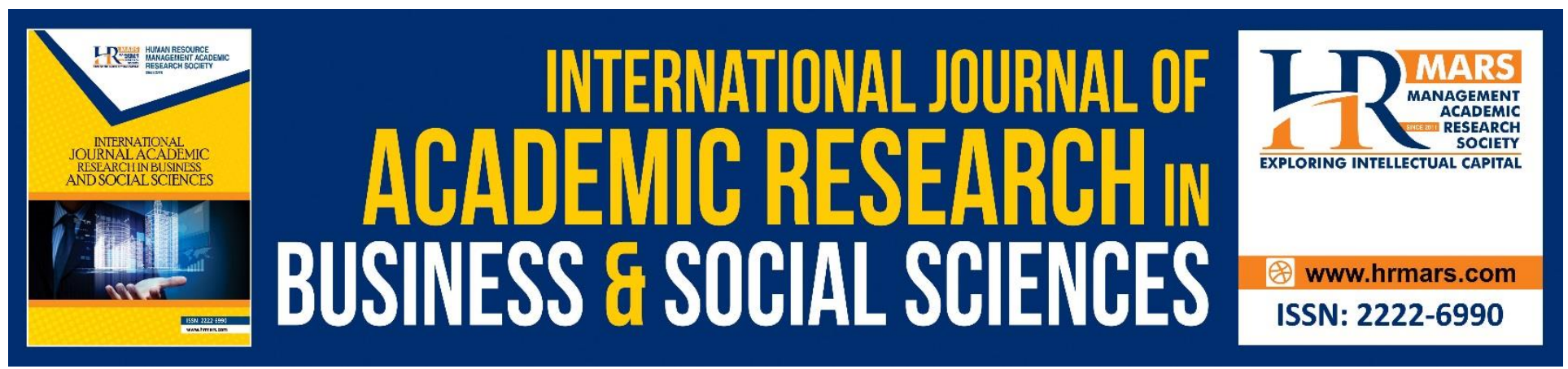

\title{
Weaknesses Concept of Existing Fixed Deposit
}

Siti Syazwani binti Suhaimi, Puspa Liza bintiGhazali, Roslida binti Abdul Razak

To Link this Article: http://dx.doi.org/10.6007/IJARBSS/v9-i1/5813

DOI: $10.6007 /$ IJARBSS/v9-i1/5813

Received: 12 Dec 2018, Revised: 27 Dec 2019, Accepted: 1 Jan 2019

Published Online: 23 Jan 2019

In-Text Citation: (SyazwanibintiSuhaimi, BintiGhazali, \& Razak, 2019)

To Cite this Article: SyazwanibintiSuhaimi, S., BintiGhazali, P. L., \& Razak, R. binti A. (2019). Weaknessess Concept of Existing Fixed Deposit. International Journal of Academic Research Business and Social Sciences, 9(1), $1283-1287$.

Copyright: (C) 2019 The Author(s)

Published by Human Resource Management Academic Research Society (www.hrmars.com)

This article is published under the Creative Commons Attribution (CC BY 4.0) license. Anyone may reproduce, distribute, translate and create derivative works of this article (for both commercial and non-commercial purposes), subject to full attribution to the original publication and authors. The full terms of this license may be seen

at: http://creativecommons.org/licences/by/4.0/legalcode

Vol. 9, No. 1, 2019, Pg. 1283 - 1287

http://hrmars.com/index.php/pages/detail/IJARBSS

JOURNAL HOMEPAGE

Full Terms \& Conditions of access and use can be found at http://hrmars.com/index.php/pages/detail/publication-ethics 


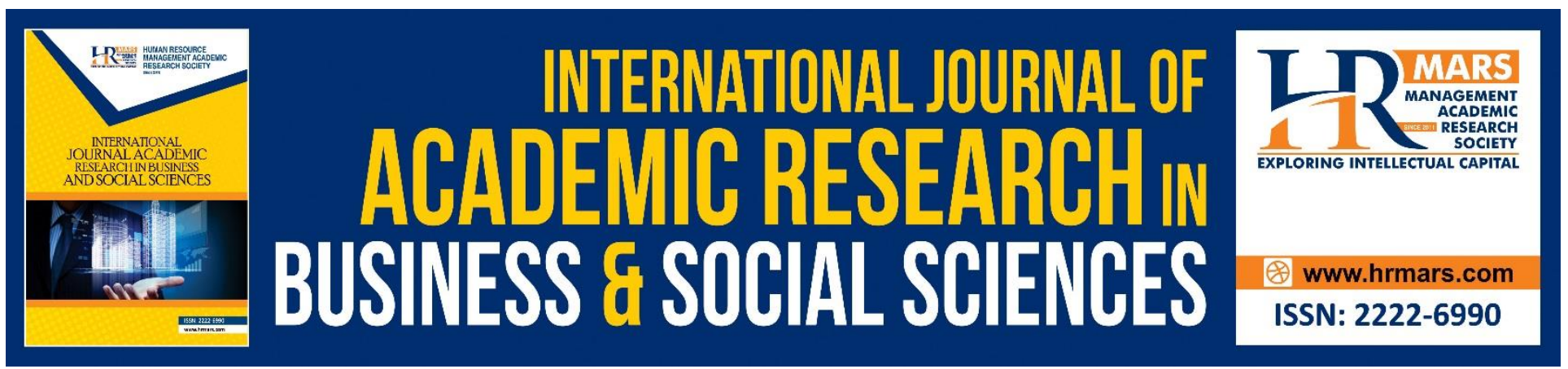

\title{
Weaknesses Concept of Existing Fixed Deposit
}

\author{
${ }^{1}$ Siti Syazwani binti Suhaimi, ${ }^{2}$ Puspa Liza bintiGhazali, ${ }^{3}$ Roslida binti \\ Abdul Razak \\ 1, 2 \& ${ }^{3}$ Faculty of Economic and Management Science, Universiti Sultan ZainalAbidin, \\ 21300 Kuala Nerus, Terengganu. Malaysia. \\ ${ }^{2}$ Corresponding Author: puspaliza@unisza.edu.my
}

\begin{abstract}
The demand for investing especially fixed deposit in Islamic banking is increasing as well as Islamic product. Through the past research found that some issues regarding this objective of this paper which are to determine the existing model fixed deposit of investment in Islamic bank, develop a new formulation of calculation for the Islamic fixed deposit based on Shariah Compliance and to survey the customer's acceptability on the new characteristics of Islamic fixed deposit product among personal account and generate some hypotheses through this issue. It has been demonstrating that three variables which contribute significantly to the acceptability in new attribute of Islamic fixed deposit are: profit from fixed deposit, all the characteristics of the product and awareness among the people. The researcher will give huge useful information in order to come out by new element integrated formula to the customer acceptance of the Islamic fixed deposit. According to this study, it may increase the acceptability customers on Islamic fixed deposit; management should implement the profit, product and awareness among the customers. This paper will provide further support to the general body of knowledge on Islamic fixed deposit by include the previous literature review in the field of Islamic investment deposit.
\end{abstract}

Keywords: Existing Model, Islamic Fixed Deposit, Profit, Product and Awareness

\section{Introduction}

Through the years, all over the world which is Muslim and non-Muslim would accept widely the Islamic banking operations. Concurrently, practice in banking and financing can be clearly found by using different practices perspectives. Based on experiment in Russian 2011, the result found that the level ratios of retail deposits is increase when entering a new deposit insurance system rather than system with no coverage deposit insurance.

The demand for Islamic banking in Malaysia is increasing as well as Islamic product rather than Conventional banking. Conventional banking interest rates are supposedly riskier due to risk investment product when compared Islamic banking profit rates which using risk-sharing attribute 
INTERNATIONAL JOURNAL OF ACADEMIC RESEARCH IN BUSINESS AND SOCIAL SCIENCES Vol. 9, No. 1, Jan, 2019, E-ISSN: 2222-6990@ 2019 HRMARS

embedded in their structure. Today, people focused more on profitable of investment in fixed deposit. There are various types of fixed deposit offered by the bank but all the investments only offer the upcoming profit and do not offer with the protection against inflation.

\section{Literature Review}

A brief explanation on the terms of our research namely product, profit and awareness will be discussed on this section. These terms should be stated from the beginning beyond the scope of this paper, thus clearly depth analysis with the relevant terms and process flow can be found. Therefore, some researchers accept this flow and used this definition rather used basis discussion on this topic.

\section{Product}

In order to survive, banks were forced to diversify its product range and use all the methods to promote them. Thus, the actual financial-banking sector can adopt the modern promotion techniques to demonstrate a scientific approach in Islamic bank product. The low level of investment in the bank has generated concerns that the average growth of advanced banking economies may be much weaker in the future (Banerjee, Kearns \& Lombardi, 2015).

Most of the investment account in Islamic bank used Mudaraba contract which is profit sharing concept and one of the platform to mobilize funds from depositors. In theory, requirements of Mudaraba contract in Islamic banks are neither guarantees the repayment of deposits nor guarantee profits. From Aziz, Awang, \& Afthanorhan (2016) prove in their research by using risk shifting in Islamic banking are more guaranteed-in-substance type of deposits rather than risk sharing in the Takaful and Tabarru' that were argued in market-oriented, but less Sharia compliant and opposite with the concept in Islamic bank.

Based on the Mustafa \& Najeeb (2018) proposed that legal challenges in the previous model including subrogation and payment of fees for guarantee can be overcome with the Shariah principle by include cash waqfShariah-Compliant Deposit Insurance (SCDIS). Hence, effective design deposit insurance schemes can meet the requirements of International Association of Deposit Insurers' Core Principles for effective deposit insurance schemes. Therefore, to encourage SCDIS application, can use this designed as an alternative of a cash waqf structure.

\section{Profit}

The existence of a sale contract and loan facility in a single transaction is one of the issues that can affect deposit products. The results of some contracts found by the researchers arrived at the following findings that some contracts about the prohibition of bay'wasalaf disagreement have no juristic disagreement. The express demand of sale or rendering of service and express or implied demand of loan alongside occur when the sale or service rendering was the most notable area of agreement on the existence of bay'wasalaf. Depositors who will put the money as loan to the bank and the bank will generate profit by putting the money into the sale and divided the dividend between the banks and their depositors as the implication of the reversed tawarruq. However, this research proves the prophetic tradition is not prohibited bay'wasalaf (Ahmad \& Ansari, 2017). 
The operationalized and revealed in the Return of Bank Capital (ROE) and Return on Mudarabah Deposits (ROMD) is marked as equity principle when Islamic banking runs on profit-sharing basis with depositors. The contractual modifications were truly redirect between bank's capitals and fixed deposits by using the result of deposit earnings in Islamic banks were higher than return on equity (ROE). As the result found of variances is low, it shows that ROEs and Islamic banks' deposit income do not reflect its risk-taking properties (Rosly \& Zaini, 2008).

In order to find the determinants by rates of profit in Islamic bank using econometric techniques which is gross domestic product, base lending rate, money supply, consumer price index and Kuala Lumpur composite index have different impact on deposits at both Islamic and non-Islamic banking systems. In recent results, some of these theories of product are not applicable to deposit Islamic banking customers. Thus, Muslims customers play an important role in the making possibility decisions based on religious belief (Haron \& Azmi, 2008).

\section{Awareness}

Clark-Murphy \& Soutar (2005) mentioned in their study that the influence factors individuals' investment decisions are based on the information structure and the factors in the market as well as market outcomes. By making profits for companies and themselves is the effort investment decisions were taken by the managers and investors.

Bank products such like level of understanding the knowledge and the services which is service delivery, marketing strategy and service cost is a factors that highlighted by the corporate customer based on perception in Islamic bank. Service delivery and deficiencies in marketing drive contribute toward their smaller loan services and market share of deposits in the Islamic bank (Al-Mhasnah et al., 2018). Based on the psychology, the behaviour biases on the people at certain age to make decisions and the young investors are higher than the elder investors due to more experienced. Young investors gain high incomes and knowledge about the investment rather than the elder investors.

\section{Conclusion}

From the literature review, we can conclude that the new formula in Islamic fixed deposit must be created, in order to attract the customer. Therefore, in the future, we need to develop a new model for the role of efficient principals and includes the minimum charge takaful coverage protection for the sake of the attraction customer in the bank (Ghazali et. al, 2017). 
INTERNATIONAL JOURNAL OF ACADEMIC RESEARCH IN BUSINESS AND SOCIAL SCIENCES

Vol. 9, No. 1, Jan, 2019, E-ISSN: 2222-6990 @ 2019 HRMARS

\section{References}

AL-Mhasnah, A., Salleh, F., Afthanorhan, A., \& Ghazali, P. (2018).The relationship between services quality and customer satisfaction among Jordanian healthcare sector. Management Science Letters, 8(12), 1413-1420.

Aziz, M. I., Afthanorhan, A., \& Awang, Z. (2016). Talent development model for a career in Islamic banking institutions: A SEM approach. Cogent Business \& Management, 3(1), 1186259.

Clark-Murphy, M., \& Soutar, G. (2005). Individual investor preferences: A segmentation analysis. The Journal of Behavioral Finance, 6(1), 6-14.

Mustafa, M. \& Najeeb, S. F. (2018), International Journal of Islamic and Middle Eastern Finance and Management, "Shariah-compliant deposit insurance scheme: a proposed additional modality[1]", https://doi.org/10.1108/IMEFM-04-2017-0090

Ahmad, M. \&Ansary, R. (2017). ISRA International Journal of Islamic Fianance, "Fiqhi views on bay'wasalaf and qard-based Islamic banking deposits accounts in Malaysia", Vol. 9 Issue: 1, pp.106-112, https://doi.org/10.1108/IJIF-07-2017-011

Banerjee, R., Kearns, J. \& Lombardi, M. (2015). BIS Quarterly Review, "(WHY) Is investment weak?"

Rosly, S. A.,Zaini, M. A. Z. (2008). Managerial Finance, "Risk-return analysis of Islamic banks' investment deposits and shareholders' fund", Vol.34 Issue: 10, pp.695-707, https://doi.org/10.1108/03074350810891010

Haron, S.\&Azmi, W. N. W. (2008). Managerial Finance, "Determinants of Islamic and conventional deposits in the Malaysian banking system",

Vol. 34 Issue: 9, pp.618-643, https://doi.org/10.1108/03074350810890976

Ghazali, P. L., Mamat Mustafa, Omar, L., N. H. M. Foziah, D. A. Guci, Y. B. Abdullah and N. E. S. B. Sazali (2017). Medical Integration Model of Family takaful For Blue Collar. Far East Journal of Mathematical Sciences (FJMS), Volume 101, Number 6, 2017, Pages 1197-1205. 